ШИЛОВ Владимир Викторович - кандидат исторических наук, доцент; заведующий кафедрой общенаучных дисциплин Березниковского филиала Пермского национального исследовательского политехнического университета (618400, Россия, Пермский край, г. Березники, ул. Химиков, 10, каб. 205; vvs595959@таil.ru); член правления Российского общества социологов (Пермское отделение)

\title{
ФЕНОМЕН ДВУХ РОССИЙСКИХ ОЛИГАРХОВ Часть 1
}

Аннотация. В статье рассматривается профессиональная и общественная деятельность двух богатейших людей России: досоветского периода (И.И. Любимов) и постсоветской эпохи (В.В. Тетюхин). Автор приводит примеры ответственного отношения к социальным проблемам рабочих и служащих возглавляемых ими сложных производств, готовности бескорыстно финансировать социально значимые проекты, мыслить как государственными, так и высокими гуманными общечеловеческими категориями.

Ключевые слова: первоначальный капитал, образование, стагнация, экономический кризис, эффективный менеджер, социально ответственный бизнес, меценатство, роль личности в истории

$\mathrm{B}_{\mathrm{r}}^{\mathrm{c}}$ современном российском обществе отношение к богатым соотечественникам часто бывает негативным. И этому есть объяснение. Переход в конце $\mathrm{XX}$ в. к рыночным отношениям, признание института частной собственности, «шоковая терапия» привели к потере вкладов у миллионов вчерашних советских людей. Непродуманная приватизация 1990-х гг. не принесла благосостояния подавляющей части населения РФ, и в то же время буквально в считанные годы очень небольшая часть россиян нажили целые состояния.

Не случайно в обществе того периода большую популярность приобрели анекдоты о «новых русских» (эдакие малообразованные, невоспитанные, хамоватые нувориши), а слово «олигарх», которое активно начали использовать с конца 1990-х гг., приобрело ярко выраженные негативные коннотации.

Известно, что термин «олигархия» начали использовать еще Платон и Аристотель. Последний использовал это слово в значении «власть богатых», противопоставляя его «аристократии», считая при этом демократию меньшим злом, в отличие от олигархии [Аристотель 1997: 271].

Французские мыслители эпохи буржуазной революции 1789 г. возродили понятие олигархии и понимали под ним «слияние политической и экономической власти», а социолог Роберт Михельс в 1911 г. даже сформулировал «железный закон олигархии», утверждая, что демократия невозможна в больших обществах: если там установится демократический режим, то он неизбежно выродится в олигархию (номенклатура в СССР, плутократия и корпоратократия в западных демократиях или компрадорская буржуазия в странах третьего мира).

Даже в современных США (образец демократии) есть немало крупных бизнесменов, которые вкладывают свои капиталы в лоббирование своих интересов политиками (для них даже есть такой сленговый термин - «толстый кот»), а группа исследователей Принстонского университета даже пришла к выводу, что в США олигархи узурпировали власть.

Несмотря на то что пресс-секретарь президента РФ Д.С. Песков сказал, что «в России нет олигархов» (так он летом 2020 г. прокомментировал слова А.Г. Лукашенко, что российские олигархи финансируют белорусскую радикальную оппозицию), данная тема и сегодня требует серьезного исследования.

Но в нашем случае понятие «олигарх», озвученное в названии статьи, имеет 
скорее символическое значение и даже заключает в себе определенное противоречие: это сверхбогатый человек, но при этом представитель социально ответственного бизнеса, меценат, патриот в самом хорошем смысле этого слова.

В данной статье представлены два «олигарха» - И.И. Любимов (досоветский период) и В.В. Тетюхин (постсоветский период России), чтобы показать, что политический режим не сильно влияет на принятие решений, поступки - они реализуются в соответствии с мировоззрением личности.

Сначала рассмотрим жизнь и деятельность богатейшего человека Российской империи, выходца из простого народа Ивана Ивановича Любимова (18381899). В XVII в. его предки Любимовы - крестьяне, в XVIII в. - церковнослужители Петропавловского собора в Перми. Первым из них, приписавшимся в пермское купечество 3-й гильдии с капиталом 8 тыс. руб., был Филипп Алексеевич Любимов (1782-1837).

Накопив средства на торговле шелковыми и хлопчатобумажными тканями, он завел новое дело - грузовые перевозки (суда для отправки купеческих товаров по водному пути). Его старший сын Иван Филиппович (1807-1864) расширил грузовые перевозки и построил небольшую канатопрядильную фабрику. Он удачно продолжил дело отца, занявшись транспортировкой не только грузов, но и пассажиров. Кроме того, он успешно проводил оптовые операции по торговле уральским железом, хлебом, солью с оборотом более 1 млн руб.

Тем не менее в уральской энциклопедии отмечается, что «наиболее яркий представитель династии Любимовых - Иван Иванович (1838-1899), старший сын И.Ф. Любимова, с именем которого связано формирование обширного комплексного хозяйства» 1 .

Примечательно, что И.И. Любимов получил лишь домашнее образование, но при этом на протяжении всей своей жизни отличался созидательной инициативой, скрупулезно вникая в промышленные дела, живо интересуясь всеми новыми технологиями. Широта его взглядов поражала всех, кто с ним общался.

В начале своей деятельности И.И. Любимов широко развил доставшееся ему от отца пароходное дело. Его отец Иван Филиппович свой первый буксирный пароход построил еще в 1855 г., а сыну в наследство оставил довольно развитое пароходное хозяйство, которое и было впоследствии умело приумножено. Так, Иван Иванович первый завел на Каме пассажирские пароходы американского типа. Не случайно он имел прозвище «русский американец».

В Пермском Прикамье в середине XIX в. значительно выросло число как пароходных компаний, так и самих пароходов. В 1858 г. англичанин Гуллет организовал в Перми завод для постройки и починки пароходов, впоследствии купленный И.И. Любимовым.

С 1863 г. устанавливается и регулярное пассажирское сообщение с Северным Прикамьем - вверх по Каме до села Новое Усолье (ныне г. Усолье, расположенный напротив г. Березники); и большую часть пассажиров и грузов на этом маршруте перевозили именно любимовские суда.

В скором времени число пароходов настолько выросло, что И.И. Любимов в 1877 г. создает специальный завод для постройки и ремонта речных судов. В этом же 1877 г. у него впервые начинают ходить двухэтажные пароходы американского типа, а первенец среди пароходов этого класса носил название «Березники».

На своем механическом заводе И.И. Любимов построил не только несколько

\footnotetext{
1 Сапоговская Л.В. Любимовы. - Уральская историческая энииклопедия. 2-е изд., перераб. и доп. (гл. ред. В.В. Алексеев). Екатеринбург: Академкнига. 2000. С. 321.
} 
речных пароходов, но даже несколько морских шхун. В 1887-1888 гг. на заводе по частному заказу господ Солина и Петелина были построены первые паровые морские шхуны «Васпуракан» и «Князь Пожарский», предназначенные для перевозок нефти и керосина по Каспийскому морю из Баку в Астрахань ${ }^{1}$.

Среди любимовских пассажирских пароходов на просторах Камы и Волги особенно выделялись три двухпалубных: «Екатеринбург» (двигатель 800 л.с., скорость до 5 миль в час; помимо пассажиров, он мог в трюмах перевозить до 30 тыс. пудов груза), упомянутый пароход «Березники», которому по роскоши отделки в то время не было равных, и теплоход «Урал».

Даже старейшие пароходные общества «Самолет», «Кавказ и Меркурий» были вынуждены ликвидировать свои дела на Каме ввиду сильной конкуренции со стороны Любимова и Каменских. Любимовские суда значительно превосходили все остальные по техническим данным, и практически по всей Каме и Волге были построены многочисленные пристани И.И. Любимова.

К концу своей жизни, в 1895 г. Иван Иванович владел 8 пассажирскими пароходами и 20 баржами стоимостью свыше 1 млн руб. (в Центральной России в 1903 г. пуд ржи стоил в среднем 88 коп.; знаменитый «федоровский» калач 5 коп., а за шестинедельного теленка просили 9 руб.).

В 1878 г. у камских пароходов появился опасный конкурент - была открыта Уральская железная дорога. Но предприимчивого И.И. Любимова это мало коснулось. Более того, именно по его инициативе горнозаводская ветвь железной дороги от Перми до станции Чусовой была продолжена до Верхней Камы, с конечной станцией «Солеварни» (ныне ж/д станция «Березники»). В тот период эта железная дорога к тому же обеспечила подвоз кизеловского угля и дала выход на водный транспорт [Мильман 1975].

В 1881 г. уже известный и удачливый предприниматель И.И. Любимов подписывает контракт и совместно с изобретателем аммиачного способа производства соды бельгийским химиком-технологом и предпринимателем Эрнестом Сольвэ (1838-1922) создает акционерное общество «Любимов, Сольвэ и $\mathrm{K}^{\mathrm{O}_{\text {» }}}$ для постройки содового завода (на территории современного г. Березники).

Бельгийский предприниматель Э.Г. Сольвэ, который еще в 1861 г. запатентовал способ промышленного производства пищевой соды, как и И.И. Любимов, тоже получил домашнее образование и первоначальный капитал для постройки своего первого небольшого заводика занял у собственного отца. Сегодня эта крупнейшая в Европе и мире бельгийская химическая компания имеет около 70 заводов, которые работают по всему миру.

На средства Э.Г. Сольвэ в 1904 г. был создан Институт социальных наук в Свободном университете Брюсселя. Научному сообществу хорошо известны Сольвеевские конгрессы: с период с 1911 по 2020 г. в Брюсселе состоялись 28 конгрессов по физике и 25 - по химии (на них выступали Макс Планк, Эрнест Резерфорд, Мария Склодовская-Кюри, Анри Пуанкаре, Альберт Эйнштейн и другие яркие деятели науки) [Шилов 2014: 79].

Именно Э.Г. Сольвэ в XIX в. разработал наиболее совершенный тогда аммиачный способ получения соды из поваренной соли и успешно начал ее получать в промышленных масштабах в Западной Европе, а в 1881 г., как указано выше, создал с И.И. Любимовым акционерное общество в Верхнекамье, что послужило началом становления химической промышленности в Российской империи [Шилов, Сафрошенко 2018: 79].

Все проекты и чертежи аппаратов и механизмов для этого нового сложного химического производства выполнялись техниками зарождающегося завода.

\footnotetext{
1 Дмитриев А.А. Летопись губернского города Перми с 1845 по 1890 год. Пермь. 1890. С. 99.
} 
Для производства соды необходима была поваренная соль, а она в больших количествах (знаменитая соль-пермянка) поступала для нужд Российской империи именно из Северного Прикамья, где уже проявлялась активная деятельность Ивана Ивановича, в т.ч. и в солеварении. Еще в 1860 г. он купил участок земли (150 га) с заброшенным солеваренным заводом Пыскорского монастыря и восстановил его.

Этот солеваренный завод, расположенный недалеко от Березников в горном городе Дедюхине, казна сдавала в аренду, и первым его арендатором стал И.И. Любимов, который первым из предпринимателей-солезаводчиков устроил здесь работу солеварниц «по баварскому способу» (по-белому), а также стал первым применять в технологическом процессе паровые машины (наряду с конным приводом).

С 1873 г. И.И. Любимов в окрестностях современных Березников практически заново организовал солеваренный промысел. Теперь из скважин с глубины 150-180 м (при помощи железных, а не деревянных труб) выкачивали естественные рассолы и путем выварки получали поваренную соль, а в качестве топлива, вместо дров, впервые был использован кизеловский уголь (80 км от Березников), чему способствовала упомянутая выше Уральская железная дорога.

Соль-пермянка пользовалась большим спросом на российском рынке из-за своих высоких вкусовых качеств и приносила большие прибыли владельцу. Получая сверхприбыли, И.И. Любимов находил им рачительное применение.

Василий Иванович Немирович-Данченко (старший брат известного театрального деятеля Владимира Ивановича Немировича-Данченко) после посещения в 1875 г. Пермского Прикамья писал: «Какая громадная разница между заведениями Любимова и другими. Любимов наиболее добросовестный из хозяев. Он не останавливается на старых способах и не успокаивается на лаврах, как его товарищи по Усолью... Березниковский солеваренный завод Любимова давал ежегодно до 2 миллионов пудов соли» ${ }^{1}$.

Россия, как и многие страны мира, во второй половине XIX в. нуждалась в производстве соды в промышленных масштабах. Д.И. Менделеев по этому поводу заметил: «Ныне нельзя себе представить развитой промышленности без потребления соды». И эту задачу во многом решил именно И.И. Любимов на своем Березниковском содовом заводе.

Сырье для производства соды (известняк) добывали во ВсеволодоВильвенском карьере (45 км от г. Березники), но первоначально Березниковский содовый завод получал сырье (за исключением рассола) из разных мест. Кокс привозили из Донбасса и Германии, аммиачную воду - из Петербурга, известняк - водным путем с Вишеры.

Созданный И.И. Любимовым Березниковский содовый завод (названный по одноименному поселку, расположенному рядом) выдал первую продукцию в июле 1883 г. По этому поводу «Журнал русского физико-химического общества» писал: «Д. Менделеев сообщает (на заседании отделения химии физико-химического общества. - Прим. В.Ш.) о том, что через П.К. Ушкова получил образец поступившей в продажу соды, добытой по аммиачному способу на заводе Любимова и Сольве. Завод находится на Каме, против Усолья, в местности, называемой Березняки (иногда в литературе писали «Березники» через букву «я». - Прим. В.Ш.). Открыл он действие с августа 1883 года. Перерабатывает местный рассол и ныне уже готовит около 1000 пудов соды ежедневно, что

\footnotetext{
${ }^{1}$ Немирович-Данченко В.И. Камаи Урал:(очерки ивпечатления). СПб: Тип. А.С. Суворина. $1890.770 \mathrm{c}$.
} 
составит в год постоянного хода около 6000 тонн, то есть всего лишь около трети существующей в России потребности на соду, которая поныне доставлялась от заграничных заводов... Считаем необходимым сообщить известие об осуществлении наконец давних русских пожеланий - иметь свою соду - и приветствуем усилия Господина Любимова поставить начатое дело до такой степени твердо на русскую почву, что он обходится на заводе, лично руководя им, одними русскими техниками» 1 .

Сам ученый с мировым именем Д.И. Менделеев 1 марта 1884 г. на заседании отделения химии Русского физического общества сообщил свое заключение о новом заводе, отметив, что сделанные анализы показали, что «березниковская сода чрезвычайно чиста и высокого качества». Уже в 1886 г. на содовом и солеваренном заводах Любимова работали около 1250 рабочих, которые производили более 1 млн пудов соли в год.

Березниковский содовый завод с конца XIX столетия стал флагманом химической промышленности Российской империи, его продукция поступала на многие предприятия регионов страны. Перед Первой мировой войной в 1913 г. Березниковский содовый завод выработал 42 тыс. т соды, а в годы Первой мировой войны его рабочие и служащие имели бронь как работники оборонного предприятия ${ }^{2}$.

Кандидат исторических наук Н.П. Баяндина пришла к такому выводу: «Любимову удалось создать хозяйство, напоминающее современную холдинговую компанию. Машиностроительные, химические и транспортные предприятия, основанные пермским купцом, дали толчок экономическому развитию Прикамья и во многом определили судьбу крупнейших его городов, профиль их промышленного развития» [Баяндина 2002: 88].

Незадолго до смерти Иван Иванович хотел завести нефтяное дело на Кавказе (успел купить землю), но последовавшая 17 февраля (по ст. стилю) 1899 г. в Ялте смерть помешала ему исполнить это начинание.

И.И. Любимов известен и как общественный деятель, меценат и просто широкой души человек. Известный прикамский краевед Перми В.С. Верхоланцев в своей книге «Город Пермь, его прошлое и настоящее», вышедшей еще в 1913 г., писал: «Благодаря своей доброте, Иван Иванович не прекращал своих предприятий даже тогда, когда они несколько лет приносили ему убытки, не желая тем лишать заработка сотен народа» [Верхоланцев 2002: 207].

Иван Иванович принимал активное участие и в политической жизни края. Старейшая газета Пермского Прикамья «Пермские губернские ведомости» (№ 109 за 1899 г.) сообщала, что с 1871 по 1874 г. и с 1876 по 1878 г. И.И. Любимов был городским головой Перми.

Кстати, его отец Иван Филиппович трижды был пермским городским головой в 1835-1838, 1844-1853 и 1859-1865 гг. И его младший брат Михаил Иванович тоже исполнял обязанности городского головы в 1879-1881 гг. ${ }^{3}$

И.И. Любимов был не только талантливым и удачливым предпринимателем, эффективным менеджером, «крепким хозяйственником», активным региональным политиком, но и представителем социально ответственного бизнеса. При Березниковском содовом заводе уже на рубеже XIX-XX вв. существовал

1 Отчет заседания отделения химии физико-химического общества. 1884. - Журнал русского физико-химического общества. Т. 16. С. 277.

2 Государственный архив Пермского края (ГАПК). Ф. Р-1035 (АО «Березниковский содовый завод). Оп. 3. Д. 7. (Сведения об ушедших в военную службу рабочих Березниковского содового завода за период с 1911 по 1918 г.)

3 Городские головы города Перми. 2003. - Комитет по делам архивов Пермской области. Пермь: ГОУ «ГАПО». С. 45. 
театр, симфонический и духовой оркестры, больница на 30 мест, даже с операционной комнатой.

Для высококвалифицированных рабочих и служащих при заводе был отстроен Березниковский поселок, в котором были не только жилые помещения, но и школа (2-классное училище), больница. Так как Любимов приглашал на новый завод лучших специалистов, то очень быстро, уже в конце 1880 -х гг., представители технической интеллигенции (!) создали кружок любителей сценического искусства, который давал спектакли в каменном доме заводского поселка (театральный зал вмещал до 300 зрителей).

Будущий нобелевский лауреат Борис Пастернак, посетивший Березниковский содовый завод (он бывал там по делам, когда служил конторщиком в Пермской губернии), в письме своему товарищу по литературным интересам С.П. Боброву от 24 июня 1916 г. назвал содовый завод «Любимов, Сольвэ и $\mathrm{K}^{\mathrm{O}}$ и и поселок при нем «маленькой промышленной Бельгией».

Не случайно, после того как в Верхнекамье в 1925 г. профессор П.И. Преображенский открыл крупнейшее в мире месторождение калийномагниевых солей, советское правительство и ученые в конце 1920-х гг. при выборе места для строительства мощного химического комбината остановилось на том месте, где уже успешно работал Березниковский содовый завод и сушествовала инфраструктура. Расчет оказался верным, и вскоре постановлением Президиума ВЦИК РСФСР от 20 марта 1932 г. был образован ныне крупнейший индустриальный центр Западного Урала - город Березники.

Плодотворная деятельность И.И. Любимова наблюдалась не только в Северном Прикамье. Упомянутый выше В.С. Верхоланцев в начале XX столетия писал: «Главным памятником о И.И. Любимове в Перми служит основанное по его инициативе пермское Алексеевское реальное училище, для помещения которого он пожертвовал свой дом» [Верхоланцев 2002: 208].

Наследник И.И. Любимова М.И. Любимов (младший брат) в 1901 г., уже после смерти старшего брата, уступил свой дом в Перми для открывшейся новой торговой школы. Он также был первым председателем Пермской уездной управы - первого органа местного самоуправления после реформ императора Александра II Освободителя, открывшегося 16 мая 1870 г.

Сам Иван Иванович Любимов не только два раза занимал должность городского головы; он много лет состоял членом учетных комитетов различных банков Перми, был гласным городской Думы, мировым судьей, действительным членом губернского статистического комитета, почетным членом научно-промышленного музея, членом совета общественной библиотеки.

С момента передачи своего жилого дома в Перми под Алексеевское реальное училище Иван Иванович стал его почетным попечителем, а также попечителем многих других учебных заведений города, например Мариинской женской гимназии.

Всего из шести наследственных домов, принадлежавших Любимовым, три были подарены городу Перми. Последние три здания до наших дней служат жителям Пермского края. Сегодня в них располагаются авиационный колледж, школа и Дом творчества юных.

В 1884 г. Иван Иванович вместе с братом Михаилом передал деревянный дом с усадьбой для убежища бедных детей. В течение 18 лет И.И. Любимов был директором Богородицкого детского приюта, который тоже благоустроил за свой счет. При его самом деятельном участии (и значительных личных пожертвованиях) было выстроено каменное здание театра; сегодня в нем располагается один из известных российских театров - Пермский академический театр оперы и балета им. П.И. Чайковского. 
Супруга И.И. Любимова Елизавета Ивановна Любимова тоже была известной в Перми и очень щедрой благотворительницей. В ее бывшем доме в Перми ныне располагается Театр юного зрителя (ТЮЗ).

В течение 25 лет Елизавета Ивановна заведовала детским приютом, вкладывая значительные денежные суммы в его обеспечение. На ее деньги в Перми был открыт и вдовий дом для одиноких женщин. Но, по злому року, эта отзывчивая и добрая женщина после революционных потрясений 1917 г. оказалась всеми брошенной и забытой, бездомной (!), видимо, постоянно голодной. На грани помешательства она ходила по улицам Перми (если верить легенде, большую часть времени она проводила на могиле мужа на кладбище при кафедральном соборе); неизвестно, когда и как умерла, и неизвестно, где похоронена (детей, к большому сожалению Ивана Ивановича и Елизаветы Ивановны, у них не было).

Но тогда, до революции, даже после смерти мужа Елизавета Ивановна Любимова продолжала благотворительные традиции семьи. Например, она пожертвовала на новую торговую школу 25000 руб., солидную по тем временам сумму, и свою библиотеку.

Состояние И.И. Любимова к концу жизни было значительным. Прикамский историк XIX века А.А. Дмитриев пишет: «В его обширном комплексном хозяйстве историки выделяют два направления - транспортно-судостроительное и содово-соляное. А в целом кредитоспособность в конце его жизни была оценена Госбанком в 60,5 млн. рублей» 1 .

Историк Н.П. Баяндина писала, что после смерти И.И. Любимова «М.И. Любимов перевел главную контору пароходства из Перми в Москву. С конца XIX века товарищество занималось транспортировкой грузов водным и железнодорожным путями, охватывая многие реки и дороги Европейской России, Урала и Сибири. Уезжая из Перми, М.И. Любимов пожертвовал свой дом под торговую школу» [Баяндина 2002: 100].

Предпринимательский талант, обширные и постоянно пополняющиеся знания, приобретенный колоссальный профессиональный и социальный опыт позволили И.И. Любимову добиться не только грандиозных успехов в бизнесе, но и большого признания современников.

Еще при его жизни, буквально через 6 лет после пуска в Березниках первого в России содового завода газета «Пермские епархиальные ведомости» (ПЕВ) в 1889 г. писала: «Он любит индустрию, как любознательный ученый человек любит науку, или как страстный певец любит приятный музыкальный инструмент» ${ }^{2}$.

За свою плодотворную и многогранную деятельность Иван Иванович Любимов имел звание коммерции советника, многие русские ордена до ордена Святого Владимира 3-й степени включительно и бриллиантовый перстень с вензелевым изображением имени великого князя Алексея Александровича, пожалованный ему за пожертвование дома реальному училищуㄹ.

Официально, по хранящимся в Государственном архиве Пермского края документам, И.И. Любимов значился следующим образом: «Коммерции советник, потомственный почетный гражданин и Пермской 1-й гильдии купец, член учетного комитета Пермского отделения Государственного банка, вероисповедания православного, имеет знаки отличия: ордена Св. Анны 3-й

1 Дмитриев А.А. 1902. Материалы для биографий памятных деятелей из Пермских уроженцев. - Труды Пермской ученой архивной комиссии. Вып. V. Пермь.

2 ГАПК. Ф. печ. изд. № 18778. Пермские епархиальные ведомости (ПЕВ), 1889. С. 168 169 .

3 Некролог. И.И. Любимов. 1899. - Уральское горное обозрение. № 9. 
степени, Св. Станислава 2-й степени, Св. Анны 2-й степени, Св. Владимира 4-й и 3-й степеней и две золотые медали для ношения на шее на Аннинской и Владимирской ленте, из купеческих детей г. Перми» ${ }^{1}$.

Не случайно за особые заслуги перед городом портрет И.И. Любимова был помещен в зале заседаний Пермской городской думы еще в дореволюционный период.

Скончался Иван Иванович в Ялте 17 февраля 1899 г. Тело его было перевезено в родную Пермь и предано земле на Архиерейском кладбище при кафедральном соборе при собрании народа в несколько тысяч человек (в 1930-х гг. на месте этого кладбища был построен пермский зоосад, и надгробие И.И. Любимова, как и других известных пермяков, было снесено).

В наши дни березниковские содовики ОАО «Березниковский содовый завод» и ООО «Сода-хлорат» считают отцом-основателем Березников и их производств удачливого и грамотного предпринимателя, неординарную и энергичную личность с государственным мышлением, мецената Ивана Ивановича Любимова.

Благодарные потомки летом 2014 г. в центре Березников, около ЦУМа, торжественно открыли памятник И.И. Любимову, на пьедестале которого высечено: «ИВАН ЛЮБИМОВ промышленник и меценат».

Современный жилой комплекс на территории Березниковской городской агломерации, новый центр и вектор развития правобережной части г. Березники, который сегодня застраивается красивыми многоэтажными домами, тоже получил название «Любимов».

\section{Список литературы}

Аристотель. 1997. Политика. Афинская полития. Сер. Из классического наследия. М.: Мысль. 458 с.

Баяндина Н.П. 2002. Пермь купеческая. 2-е изд., испр. и доп. Пермь: Пушка. 158 с.

Верхоланцев В.С. 2002. Город Пермь, его прошлое и настоящее. Пермь. 3-е изд. $261 \mathrm{c}$.

Мильман Э.М. 1975. История первой железнодорожной магистрали Урала (70-90 годы ХІХ в.) Пермь. 191 с.

Шилов В.В. 2014. Бельгия глазами россиянина: историко-социологические очерки. Пермь: Березниковский филиал ПНИПУ. 122 с.

Шилов В.В., Сафрошенко О.Н. 2018. Содовый на Каме. Посвящ. 135-летию Березниковского содового завода. 3-е изд., доп. Пермь: Литер-А. 256 с.

\section{THE PHENOMENON OF TWO RUSSIAN OLIGARCHS}

\section{Part 1}

Abstract. The article considers the professional and social activities of the two richest people in Russia of the pre-Soviet period (I.I. Lyubimov) and the post-Soviet era (V.V. Tetyukhin). The author provides an example of a responsible attitude to

\footnotetext{
${ }^{1}$ ГАПК. Ф. 113. ОП. 1. Д. 241. Л. 1(об).
} 
social problems of workers and employees of complex industries headed by them, willingness to finance socially significant projects, thinking in both state and high, humane universal categories.

Keywords: initial capital, education, stagnation, economic crisis, effective manager, socially responsible business, patronage, role of individual in history

СТРОГАНОВ Алексей Валерьевич - аспирант кафедры истории и регионоведения Московского гуманитарного университета (111395, Россия, г. Москва, ул. Юности, 5; stroganovalexеy@yahoо. com)

\title{
ФЕНОМЕН ЖЕНСКОГО ПРОТЕСТА НА СЕЛЕ В МОСКОВСКОЙ ОБЛАСТИ В ПЕРИОД КОЛЛЕКТИВИЗАЦИИ
}

\begin{abstract}
Аннотация. В статье представлена интерпретация женского протеста на селе в период коллективизации, так называемых бабьих бунтов. Автор предпринимает попытку объяснить причины возникновения данного феномена, а также проанализировать поведенческие и мотивационные особенности сельских женщин на фоне происходящих событий, связанных с коллективизацией. Автор рассматривает закономерность, заключающуюся в частом доминировании женского протеста над мужским. Основой документального материала послужили архивные источники Рязанского и Калужского округов Московской области.
\end{abstract}

Ключевые слова: крестьянство, коллективизация, колхозы, протест, хлебозаготовки, раскулачивание

$\mathrm{H}$ а рубеже 1920-1930-х гг. в условиях коллективизации в СССР стихийно возникло явление женского протеста, именуемого «бабьими бунтами». Данный феномен своими корнями уходит в начавшиеся еще со второй половины XIX в. структурные изменения в жизни российской деревни. С того времени огромная часть крестьян, особенно из нечерноземных районов страны, начали регулярно уходить из своих деревень в город на заработки - так называемое отходничество. Женщины последовали примеру мужчин и массово стали устраиваться в городе кухарками, горничными, сиделками, прачками - иными словами, разного рода прислугой. Вся эта крестьянская масса перенимала бытовые привычки горожан, которые были гораздо более радикальными, чем у крестьян, заменяя, таким образом, свою патриархальную ментальность, основанную на господстве и подчинении младших членов семьи - старшим, жен - мужьям, детей - родителям, на возникающие образы новых современных мужчин и женщин. В деревне формировался новый менталитет крестьянина собственника, хозяина, который своим трудом кормит не только свою семью, но и всю не участвующую в процессе сельского производства страну, главным образом рабочих с промышленных предприятий.

Проблематика темы актуальна в связи с изучением роли женщин в различных сферах жизнедеятельности в период советской истории. Особое значение имел фактор связи женского менталитета с традициями родного края, малой родины, своего народа [Васильев 2018: 47-48, 64]. Игнорирование данного фактора могло иметь негативные последствия, в т.ч. политические [Васильев, Шепелев 2016: 12].

К периоду начала советской коллективизации ситуация в деревне была нака- 